\title{
Pemberdayaan Kesehatan Reproduksi Remaja Anggota Bina Keluarga Remaja (BKR) melalui Participatory Rural Appraisal $(P R A)$ di Desa Potorono, Kabupaten Bantul, Daerah Istimewa Yogyakarta
}

\author{
Ratu Matahari, Khoiriyah Isni, Fitriana Putri Utami \\ Fakultas Kesehatan Masyarakat, Universitas Ahmad Dahlan \\ E-mail: ratu.matahari@ikm.uad.ac.id; khoiriyah.isni@ikm.uad.ac.id; \\ fitriana.utami@ikm.uad.ac.id
}

\section{Article History:}

Received: Sept $9^{\text {th }} 2020$

Revised: Feb 11 th 2021

Accepted: May 30th 2021

\section{Keywords:}

Youth Family Development, Reproductive Health, Health Communication

\begin{abstract}
The lack of open communication between parents and children triggers adolescents to engage in deviant behavior, including premarital sex. This activity aims to improve the knowledge and communication skills of BKR members regarding adolescent reproductive health as an effort to reduce the incidence of unwanted pregnancy and early marriage in Padukuhan Mertosanan Kulon, Potorono Village. The interventions provided were in the form of counseling and roleplay as well as discussion of case studies related to adolescent reproductive health. Based on the results of the intervention, knowledge about reproductive health increased, participants were skilled in solving problems in case studies and were able to practice health communication to adolescents. It is very important to carry out regular adolescent reproductive health education activities for BKR members.
\end{abstract}

\section{Pendahuluan}

Era baru revolusi industri 4.0 atau industri berbasis teknologi informasi membuka tantangan baru bagi seluruh lapisan masyarakat Indonesia. Perubahan tersebut tidak hanya berdampak pada sektor industri tetapi juga pada aspek kehidupan sosial kemasyarakatan lainnya. Akses internet di kalangan remaja bagaikan dua sisi mata uang. Dengan kata lain, internet akan mempermudah remaja dalam mengakses kebutuhan informasi dan melakukan aktivitas yang produktif berbasis teknologi, namun di sisi lain akan menjadi bumerang apabila digunakan untuk mengkakses beberapa hal yang kontraproduktif. Faktanya, sebagian besar remaja mengakses internet dengan tujuan untuk mengoperasikan media sosial $(83,13 \%)^{1}$.

\footnotetext{
${ }^{1}$ Herdina Indrijati, “Penggunaan Internet Dan Perilaku Seksual Pranikah Remaja,” Prosiding Temu Ilmiah Nasional X Ikatan Psikologi Perkembangan Indonesia 1, no. 17 (2017): 44-51, http://jurnal.unissula.ac.id/index.php/ippi/article/view/2178.
} 
Remaja merupakan kelompok sosial yang berada pada rentang usia 10-19 tahun. ${ }^{2}$. Perubahan yang dialami remaja menimbulkan rasa ingin tahu terhadap hal-hal baru yang menarik daya pikir dan imajinasinya termasuk topik seksual ${ }^{3}$. Masalah kesehatan reproduksi yang sering dialami oleh remaja diantaranya adalah seks pranikah, kehamilan tidak diinginkan (KTD), aborsi illegal, penggunaan obat-obat terlarang, penggunaan alat kontrasepsi tanpa konsultasi tenaga kesehatan, dan tertular penyakit menular seksual termasuk HIV dan AIDS ${ }^{4}$.

Prevalensi remaja yang melakukan perilaku seksual sebelum menikah (premarital seksual) berdasarkan hasil Survei Demografi dan Kependudukan Indonesia (SDKI) tahun 2012 sebanyak 3,7 juta (9,3\%) dan meningkat pada tahun 2017 yaitu sebesar 50\% remaja putra dan $30 \%$ remaja putri menyatakan pernah melakukan hubungan seksual pranikah ${ }^{5}$. Berdasarkan beberapa kajian ilmiah menjelaskan bahwa masalah kesehatan reproduksi remaja disebabkan beberapa faktor diantaranya adalah minimnya pengetahuan terkait kesehatan reproduksi, pergaulan bebas, kurangnya pendidikan kesehatan reproduksi, serta kurangnya peran orang tua dalam pola asuh ${ }^{6}$. Minimnya keterbukaan komunikasi antara orangtua kepada anak menjadi pemicu remaja melakukan perilaku yang menyimpang diantaranya adalah perilaku seks pranikah pada remaja ${ }^{7}$. Situasi tersebut diperkuat dengan nilai sosial masyarakat yang memandang bahwa seks merupakan hal yang tabu untuk diperbincangkan ${ }^{8}$.

Beberapa penelitian yang telah dilakukan menjelaskan bahwa perilaku seks sebelum menikah pada remaja di Kabupaten Bantul erat kaitannya dengan kualitas komunikasi orang tua kepada anak ${ }^{9}$. Hal tersebut juga diperkuat dengan hasil pengabdian kepada masyarakat di wilayah Cokrodiningratan, Kota Yogyakarta yang

${ }^{2}$ Anas Rahmad Hidayat and Isnani Nurhayati, "Peran Orang Tua Dalam Pencegahan Perilaku Sex Pranikah Pada Remaja Di Bantul," Jurnal Formil (Forum Ilmiah) Kesmas Respati 5, no. 1 (2020): 71.

3 Livia Dwi Ramadhani, Tantut Susanto, and Latifa Aini Susumaningrum, "POLA KOMUNIKASI KELUARGA DENGAN PERILAKU SEKSUAL BERISIKO PADA REMAJA TUNARUNGU DI SEKOLAH LUAR BIASA KECAMATAN PATRANG KABUPATEN JEMBER," Jurnal Kesehatan Reproduksi 10, no. 1 (2019): 5158.

${ }^{4}$ Hery Ernawati, "Pengetahuan Kesehatan Reproduksi Remaja Di Daerah Pedesaan," Indonesian Journal for Health Sciences 2, no. 1 (2018): 58.

5 BKKBN, "Survei Demografi Dan Kesehatan: Kesehatan Reproduksi Remaja 2017," Badan Kependudukan dan Keluarga Berencana Nasional (2017): 1-606, http://www.dhsprogram.com.

6 Afiyatun, "Hubungan Peran Orang Tua Dengan Tingkat Pengetahuan Tentang Kesehatan Reproduksi Remaja Dalam Upaya Pencegahan Kehamilan Tidak Di Inginkan (Ktd) Di Sma N 2 Banguntapan Yogyakarta," Jurnal Keperawatan 2, no. 1 (2018).

${ }^{7}$ Desi Maulida and Safrida Safrida, "Komunikasi Orang Tua Dan Anak Dalam Pencegahan Seks Pranikah," Jurnal Komunikasi Global 9, no. 1 (2020): 97-114.

8 Maria Margaretha Okky Triani, "Isu Seksualitas Dalam Komunikasi Keluarga," Acta Diurna 16, no. 1 (2020): 70-91.

${ }^{9}$ Sari Setiawati, Persepsi Remaja Terhadap Pernikahan Dini Di SMAN 1 Banguntapan Kabupaten Bantul, 2017; Hidayat and Nurhayati, "Peran Orang Tua Dalam Pencegahan Perilaku Sex Pranikah Pada Remaja Di Bantul." 
menjelaskan bahwa minimnya keterlibatan peran orang tua mendampingi anak untuk memenuhi kebutuhan informasi terkait kesehatan reproduksi ${ }^{10}$. Sebuah penelitian yang telah dilakukan di Kecamatan Banguntapan, Kabupaten Bantul, D.I Yogyakarta menemukan bahwa pengawasan yang dilakukan orang tua pada pergaulan remaja dalam rangka mencegah kehamilan tidak diinginkan adalah berupa penerapan jam malam, mengecek telepon peribadi remaja dan berusaha mengenal secara mendalam teman sepermainan remaja. Namun, pesan terkait kesehatan reproduksi masih sangat jarang diberikan oleh orang tua kepada anak remajanya. Hal ini dikarenakan keterbukaan komunikasi antara orang tua dan remaja yang masih kurang11.12

Berdasarkan hasil wawancara mendalam kepada Kepala Padukuhan Mertosanan Kulon didapatkan informasi bahwa terdapat kasus Kehamilan Tidak Diinginkan (KTD) pada remaja dan kemudian berlanjut pada pernikahan dini. Menurut pengakuan Kepala Dukuh Mertosanan Kulon, kejadian KTD disebabkan karena minimnya pengetahuan pengetahuan kesehatan reproduksi pada remaja dan orang tua. Budaya tabu untuk membahas masalah kesehatan reproduksi remaja juga masih menjadi "momok" antara kedua belah pihak. Berkaitan dengan situasi tersebut, Padukuhan Mertosanan Kulon membentuk Bina Keluarga Remaja yang merupakan program inisiasi Badan Kependudukan dan Keluarga Berencana Nasional (BKKBN) Daerah Istimewa Yogyakarta untuk menekan laju kasus KTD. Sebagai kegiatan rintisan, maka para anggota BKR merupakan keluarga yang memiliki anak remaja belum memiliki bekal pengetahuan yang cukup untuk memberikan edukasi kesehatan reproduksi ramah remaja.

Mengapa peranan keluarga sangat penting? Berdasarkan sebuah penelitian menyatakan bahwa pendidikan yang utama berasal dari keluarga, sehingga menjadi hal yang ideal apabila edukasi seksual pada remaja berasal dari orang tua ${ }^{13}$. Hal tersebut juga diperkuat penelitian yang telah dilakukan pada siswa SMP yang menunjukkan bahwa responden penelitian tersebut sangat menginginkan edukasi terkait seks dari orang tua sendiri14. Didasari hal tersebut, maka kegiatan pengabdian kepada masyarakat ini dilakukan dengan memberikan edukasi kesehatan reproduksi remaja melalui penyuluhan serta kegiatan ketrampilan yaitu dengan teknik role play serta diskusi

10 Khoiriyah Isni et al., "Upaya Penanggulangan Masalah Kesehatan Reproduksi Remaja Di Kecamatan Jetis, Yogyakarta," Jurnal Pemberdayaan: Publikasi Hasil Pengabdian Kepada Masyarakat 4, no. 1 (2020): 31-36.

11 Fitriana Putri Utami, "Praktik Orang Tua Dalam Pengawasan Pergaulan Remaja Guna Mencegah Kehamilan Tidak Diinginkan (KTD)," Care: Jurnal Ilmiah Ilmu Kesehatan 7, no. 2 (2019): 7-15. Di Bantul."

${ }^{12}$ Hidayat and Nurhayati, "Peran Orang Tua Dalam Pencegahan Perilaku Sex Pranikah Pada Remaja

13 Widayati Lestari, "Model Komunikasi Pendidikan Seksualitas Orang Tua Pada Remaja Pendahuluan Maraknya Perilaku Seksual Remaja Saat Ini Sudah Semakin Memprihatinkan . Perkembangan Zaman Rangsangan Dari Lingkungan Seperti Film , TV , VCD Tentang Perilaku Seksual Serta Faktor," Indonesian Journal of Islamic Psychology 1, no. 1 (2019): 55-80.

14 Sisca Dwi Puspita Arum Dwi Anjani, "Sapa Orang Tua Dengan Pengetahuan Remaja Tentang Kesehatan Reproduksi Remaja,” Jurnal Kebidanan 5, no. 4 (2019): 389-395. 
kelompok studi kasus. Kegiatan intervensi tersebut bertujuan untuk meningkatkan pengetahuan, ketrampilan komunikasi, serta kemampuan menyelesaikan masalah terkait kesehatan reproduksi remaja sebagai upaya mencegah meningkatnya kejadian KTD dan pernikahan dini di Padukuhan Mertosanan Kulon.

\section{Metode}

Kegiatan pengabdian kepada masyarakat ini telah dilaksanakan di Balai Padukuhan Mertosanan Kulon. Kegiatan pelatihan ini dilaksanakan dengan melibatkan 25 orang anggota kelompok Bina Keluarga Remaja (BKR) Dusun Mertosanan Kulon. BKR merupakan keluarga yang memiliki anak berusia remaja sehingga menjadi sasaran yang tepat kegiatan ini. Pelatihan ini dilaksanakan selama 2 hari dengan total waktu pelaksanaan kegiatan selama 12 jam. Kegiatan ini dilaksanakan dengan pendekatan Participatory Rural Appraisal (PRA) ${ }^{15}$. Pendekatan PRA ini bertujuan untuk membantu memahami situasi di wilayah secara lebih terperinci sehingga tim pengabdi dapat mengetahui pengetahuan, pengalaman, serta gagasan masyarakat yang pada akhirnya dapat mendukung keberlanjutan pelaksanaan program BKR.

Adapun langkah-langkah pelaksanaan kegiatan pengabdian kepada masyarakat digambarkan sebagai berikut:
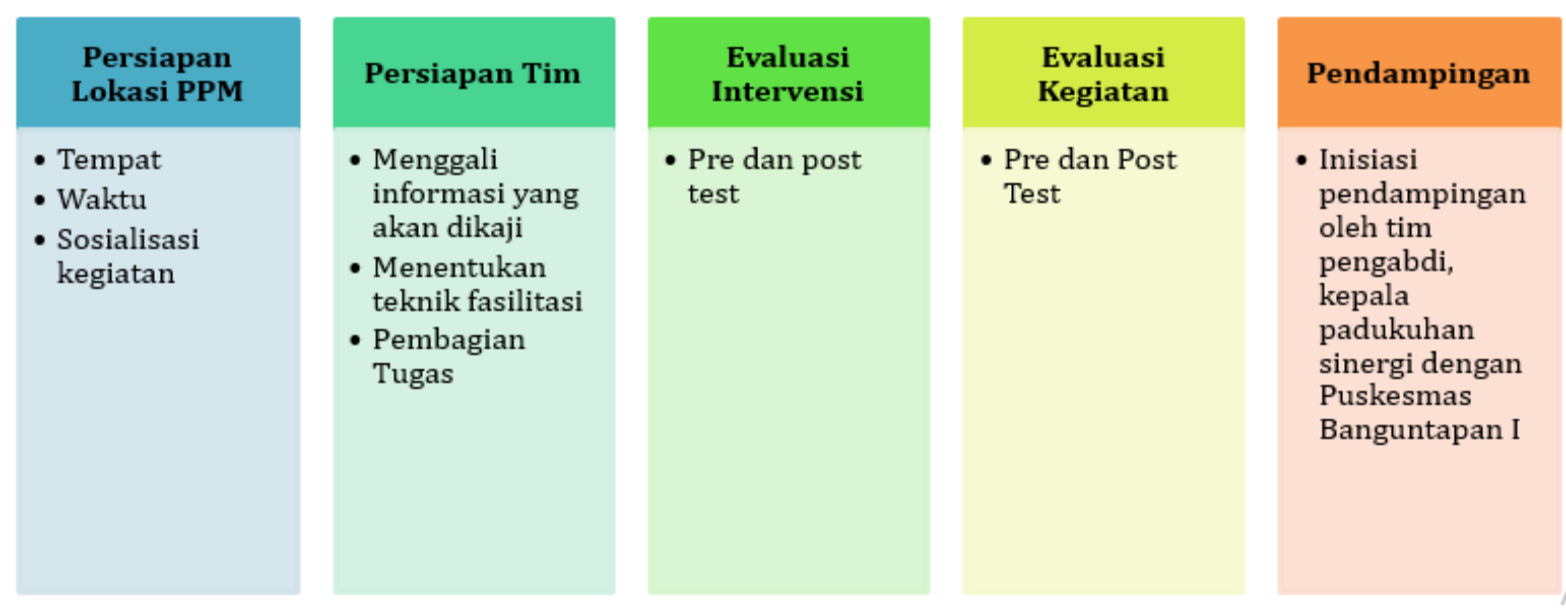

Gambar 1. Langkah-langkah pelaksanaan kegiatan dengan pendekatan PRA

Berdasarkan Gambar 1 dapat dijelaskan tahapan pelaksanaan kegiatan pengabdian kepada masyarakat yang telah dilakukan sebagai berikut:

15 Hernik Farisia Moh.Ansori, Agus Afandi, Ries Dyah Fitriyah, Rizka Safriyani, PendekatanPendekatan Dalam University Community Engagement (UIN Sunan Ampel Press, 2021). 
Tahap Persiapan lokasi, pada tahapan ini tim pengabdi melakukan koordinasi kepada Kepala Padukuhan Mertosanan Kulon untuk menetapkan tempat, waktu, dan sosialisasi pelaksanaan kegiatan.

Tahap Persiapan Tim, sebelum melakukan kegiatan pengabdian kepada masyarakat tim pengabdi melakukan analisis masalah dengan cara indepth interview kepada Kepala Padukuhan.

Tahap Evaluasi Intervensi, sebagai langkah untuk menilai keberhasilan intervensi yang dilakukan maka tim pengabdi memberikan pre dan post test yang bertujuan untuk mengukur pengetahuan kelompok sasaran terkait kesehatan reproduksi remaja sebelum dan sesudah dilakukan intervensi.

Tahap Evaluasi Kegiatan, pada tahapan ini tim pengabdi memberikan formulir penilaian kepada kelompok sasaran untuk menilai kegiatan yang telah dilakukan dengan menilai tema elatihan, kelengkapan materi, sikap penyelenggaran, alat bantu yang digunakan, fasilitator ( penguasaan masalah, cara penyajian, manfaat materi, interaksi dengan peserta).

Tahap Pendampingan, Pada tahapan ini tim pengabdi melakukan pendampingan kepada kelompok sasaran untuk menjadi fasilitator kesehatan reproduksi ramah remaja dengan meminta kelompok sasaran melakukan praktik fasilitasi. Iniasi program pendampingan peningkatan edukasi dan ketrampilan kepada kelompok sasaran dengan sinergitas antara institusi akademik (Fakultas Kesehatan Masyarakat Universitas Ahmad Dahlan, lokasi pengabdian, dan Puskesmas Banguntapan I.

\section{Hasil Pendampingan}

Hasil kesepakatan pada tahap persiapan lokasi adalah kegiatan pengabdian kepada masyarakat dilaksanakan di gedung serbaguna Padukuhan Mertosanan Kulon pada tanggal 7-9 Juli 2019 dengan melibatkan 25 anggota BKR yang diinformasikan melalui grup whatsapp oleh Ketua Padukuhan Mertosanan Kulon.

Berdasarkan Tahap persiapan tim didapatkan informasi bahwa di Padukuhan Mertosanan Kulon masih terjadi kasus KTD (lebih dari 1) yang berimplikasi pada kejadian pernikahan dini, Bina Keluarga Remaja belum aktif melakukan kegiatan kemasyarakatan meskipun sudah diinisiasi pada tahun 2018. Kemudian tim melakukan kaji literature untuk menentukan teknik fasilitasi yang dinilai sesuai untuk diberikan kepada kelompok sasaran yaitu penyuluhan bertujuan meningkatkan pengetahuan terkait kesehatan reproduksi remaja, role play bertujuan untuk meningkatkan komunikasi antar orangtua dan remaja mengenai kesehatan reproduksi, dan studi kasus bertujuan untuk meningkatkan ketrampilan kelompok sasaran dalam menyelesaikan masalah serta mengambil keputusan terkait masalah kesehatan reproduksi remaja. 
Materi yang disampaikan oleh fasilitator diantaranya adalah (1). Fenomena perilaku negative remaja dan permasalahan kesehatan reproduksi remaja (diperdalam dengan problem mapping); (2) Psikologi remaja; (3) Orang tua dan Remaja; (4) Peran Orangtua dalam tumbuh kembang remaja. Sedangkan untuk materi role play adalah ketrampilan komunikasi dasar orang tua dan anak, materi ketrampilan pemecahan masalah yaitu kasus seksual remaja di media sosial.

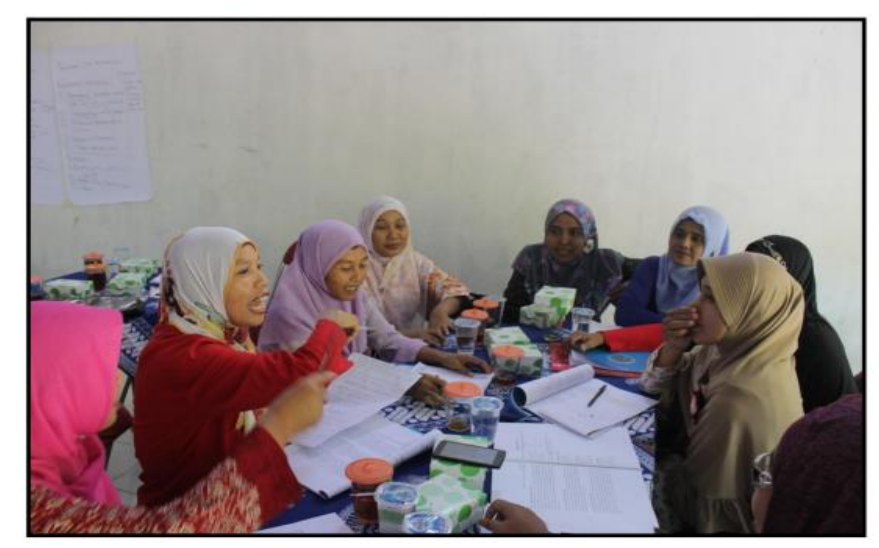

Gambar 2. Peserta melakukan problem mapping pada kegiatan studi kasus

Berdasarkan evaluasi intervensi yang dilakukan didapatkan hasil bahwa pengetahuan kelompok sasaran terkait kesehatan reproduksi remaja meningkat sebelum dan sesudah dilakukan intervensi. Nilai rata-rata 73,nilai terendah 56, tertinggi 86 dan nilai rata-rata setelah dilakukan intervensi adalah 78 , nilai terendah 70 , dan nilai tertinggi 86. Peningkatan nilai pengetahuan tersebut dapat menunjukkan bahwa kegiatan intervensi yang dilakukan memberikan dampak positif terhadap kelompok sasaran. Hal tersebut dapat dilihat pada Tabel 1 berikut ini:

Tabel 1. Hasil Analisis Uji T-Berpasangan

\begin{tabular}{l|c|c|c|c|c}
\hline \multicolumn{1}{c|}{ Intervensi } & Min & Max & Mean & Sign & CI (95\%) \\
\hline Pre-test & 56 & 86 & 73,0 & 0,001 & $-7,31-(-1,03)$ \\
Post-test & 70 & 86 & 78,0 & & \\
\hline
\end{tabular}

Berdasarkan evaluasi kegiatan yang dilakukan didapatkan hasil bahwa kelompok sasaran menilai bagus dengan pelaksanaan kegiatan ini baik dalam hal tema, kelengkapan materi, sikap penyelenggara, serta penilaian terhadap narasumber. Hal tersebut dapat dilihat pada tabel 2 berikut ini: 
Tabel 2. Evaluasi Kegiatan

\begin{tabular}{|c|c|c|c|c|c|}
\hline Kategori penilaian & $\begin{array}{c}\text { Burulk } \\
(9 \%)\end{array}$ & $\begin{array}{c}\text { Kurang } \\
(\%)\end{array}$ & $\begin{array}{c}\text { Cukup } \\
(96)\end{array}$ & $\begin{array}{c}\text { Bagus } \\
(\%)\end{array}$ & $\begin{array}{c}\text { Memu } \\
\text { askau } \\
(0 \% 6)\end{array}$ \\
\hline \multicolumn{6}{|l|}{ Pelaksanaan Pelatiban } \\
\hline Tema pelatihan & 0,0 & 0,0 & 0,0 & 75,0 & 25,0 \\
\hline Kelengkapan materi & 0,0 & 0,0 & 12,5 & 70,8 & 16,7 \\
\hline Siksp penyelenggara & 0,0 & 0,0 & 0,0 & 58,3 & 41,7 \\
\hline Alat bentu & 0,0 & 0,0 & 16,7 & 79,1 & 0,42 \\
\hline \multicolumn{6}{|l|}{ Narasumber $\mathrm{A}$} \\
\hline Penguasan masalsh & 0,0 & 0,0 & 0,0 & 54,2 & 45,8 \\
\hline Cara penyajian & 0,0 & 0,0 & 4,2 & 45,8 & 54,2 \\
\hline Manfagt materi & 0,0 & 0,0 & 0,0 & 58,3 & 41,7 \\
\hline Interaksi dengan peserts & 0,0 & 0,0 & 8,4 & 45,8 & 45,8 \\
\hline Penggunaen alat bantu & 0,0 & 0,0 & 12,5 & 62,5 & 20,8 \\
\hline \multicolumn{6}{|l|}{ Narasumber B } \\
\hline Penguasaen masalah & 0,0 & 0,0 & 0,0 & 69,5 & 30,5 \\
\hline Cara penyajian & 0,0 & 0,0 & 0,0 & 60,8 & 39,1 \\
\hline Manfaet materi & 0,0 & 0,0 & 0,0 & 56,5 & 43,5 \\
\hline Interaksi dengan peserta & 0,0 & 0,0 & 0,0 & 65,2 & 34,8 \\
\hline Penggunsen alst bantu & 0,0 & 0,0 & 13,0 & 78,2 & 8,6 \\
\hline \multicolumn{6}{|l|}{ Narasumber $\mathrm{C}$} \\
\hline Penguasaen masalah & 0,0 & 0,0 & 0,0 & 79,2 & 20,8 \\
\hline Cara penyajian & 0,0 & 0,0 & 0,0 & 45,8 & 54,2 \\
\hline Manfast materi & 0,0 & 0,0 & 0,0 & 66,7 & 33,3 \\
\hline Interaksi dengan peserta & 0,0 & 0,0 & 0,0 & 63,6 & 36,4 \\
\hline Penggunsen alat bantu & 0,0 & 0,0 & 18,1 & 77,3 & 4,5 \\
\hline \multicolumn{6}{|l|}{ Lain-lain } \\
\hline Maksnan & 0,0 & 0,0 & 20,8 & 54,2 & 25,0 \\
\hline Sound System & 0,0 & 0,0 & 25,0 & 62,5 & 12,5 \\
\hline Gedung / ruangan & 0,0 & 0,0 & 41,7 & 37,5 & 12,5 \\
\hline
\end{tabular}

Berdasarkan proses pendampingan yang telah dilakukan didapatkan hasil bahwa BKR telah melakukan kegiatan sosial kemasyarakat yaitu dengan memberikan edukasi kesehatan reproduksi kepada masyarakat di Padukuhan Mertosanan Kulon dengan anggota BKR sebagai fasilitator edukasi. Kegiatan penyuluhan kesehatan reproduksi dilakukan mulai secara rutin bersamaan dengan pelaksanaan pertemuan rutin dasawisma (satu kali/bulan).

\section{Diskusi}

Kesehatan reproduksi meupakan yang tabu untuk didiskusikan. Budaya serta nilai-nilai sosial kemasyarakatan di Indonesia dan Yogyakarta khususnya masih dominan dipengaruhi oleh nilai-nilai agama maupun kepercayaan masyarakat yang kuat sehingga 
sangat sensitive untuk membahas mengenai hal-hal yang bersifat personal ${ }^{16}$. Remaja sendiri merupakan kelompok masyarakat yang memiliki rasa ingin tahu yang tinggi dan terjadi perubahan pada diri mereka baik dari sisi fisik, psikologis, maupun biologis sehingga sangat memerlukan informasimerupakan kelompok masyarakat yang memerlukan informasi terkait seksualitas. Sebuah studi menunjukkan bahwa remaja sangat minim mendapatkan akses informasi terkait kesehatan reproduksi yang komprehensif baik di sekolah, rumah maupun di pelayanan kesehatan. Hal tersebut mendorong remaja untuk memenuhi rasa ingin tahu dengan mengakses informasi terkait kesehatan reproduksi dari media massa ataupun sumber lain yang belum teruji kebenarannya ${ }^{17}$.

Minimnya akses informasi terkait kesehatan reproduksi sangat berkaitan dengan dengan pengetahuan serta pemahaman individu terhadap kesehatan reproduksi. Hal tersebut berhubungan dengan cara berkomunikasi antara remaja dengan orang terdekat (termasuk orang tua). Oleh sebab itu, pemerintah melalui Badan Kependudukan dan Keluarga Berencana Nasional (BKKBN) membentuk Bina Keluarga Remaja (BKR) yang berfokus kepada penguatan keluarga yang memiliki anak remaja untuk dibekali informasi tentang kesehatan reproduksi remaja 18. Intervensi yang tepat untuk memenuhi kebutuhan pengetahuan kelompok sasaran terkait kesehatan reproduksi dilakukan dengan metode penyuluhan dan role play. Faktor yang memegang peranan penting dalam pembentukan sikap seseorang terhadap kegiatan pendidikan dan pelatihan adalah reaksi orang tersebut berupa reaksi suka atau tidak suka ${ }^{19}$.

Teori menyebutkan bahwa komunikasi merupakan wujud ketrampilan yang dapat dilakukan apabila seseorang memiliki pengetahuan yang baik ${ }^{20}$.Menurut penelitian terdahulu didapatkan informasi bahwa mayoritas orang tua $(57,1 \%)$ merasa sulit berkomunikasi dengan anak terkait seks. Hal tersebut dipengaruhi oleh beberapa hal diantaranya kurangnya pengetahuan terkait kespro remaja dan ketrampilan berkomunikasi, nilai budaya, dan rasa tabu untuk berbicara mengenai kesehatan

${ }^{16}$ Izzatul Arifah, Nugraheni Isna Muna, and Izdihar Azzah Paramastri, “Does Indonesian Adolescent Counseling and Information Center Affect Adolescent Reproductive Health Outcome ?," EurAsian Journal of BioSciences 14, no. April (2020): 5347-5354.

17 Donna M. Denno, Andrea J. Hoopes, and Venkatraman Chandra-Mouli, "Effective Strategies to Provide Adolescent Sexual and Reproductive Health Services and to Increase Demand and Community Support," Journal of Adolescent Health 56, no. 1 (2015): S22-S41.

${ }^{18}$ Niken Meilani, Zahroh Shaluhiyah, and Antono Suryoputro, "Perilaku Ibu Dalam Memberikan Pendidikan Seksualitas Pada Remaja Awal," Kesmas: National Public Health Journal 8, no. 8 (2014): 411.

19 Cahya Wibawa, "Perbedaan Efektifitas Metode Demonstrasi Dengan Pemutaran Video Tentang Pemberantasan DBD Terhadap Peningkatan Pengetahuan Dan Sikap Anak SD Di Kecamatan Wedarijaksa Kabupaten Pati," The Indonesian Journal of Health Promotion 2, no. 2 (2007): 115-129.

${ }^{20}$ Nuzliati Tahir Djama, "Kesehatan Reproduksi Remaja," Jurnal Kesehatan Poltekkes Ternate 10, no. 1 (2017): 30 . 
reproduksi remaja ${ }^{21}, 22$. Pendekatan PRA ini mampu menggerakkan kelompok sasaran untuk mengaktifkan kegiatan BKR setalah mendapatkan inisiasi program penyuluhan, role play, dan studi kasus. Hal ini sejalan dengan hasil pengabdian kepada masyarakat bahwa PRA mampu mengatasi problem pernikahan dini di Desa Rejosari, Temanggung 23 .

\section{Kesimpulan}

Kegiatan pengabdian kepada masyarakat memberikan dampak positif terhadap pengetahuan dan ketrampilan komunikasi dan memberikan solusi terhadap masalah kesehatan reproduksi remaja yang terjadi di Padukuhan Mertosanan Kulon. Peran Bina Keluarga Remaja sangat penting untuk menurunkan kejadian Kehamilan Tidak Diinginkan yang berimplikasi terhadap pernikahan dini. Fasilitasi pendampingan kepada anggota BKR perlu dilakukan secara berkala dengan melibatkan lembaga akademisi serta bersinergi dengan institusi terkait baik pemerintah maupun swasta.

\section{Pengakuan}

Penulis mengucapkan terimakasih kepada Lembaga Penelitian dan Pengembangan (LPPM) Universitas Ahmad Dahlan yang telah mendanai kegiatan pengabdian kepada masyarakat ini, anggota Bina Keluarga Remaja (BKR) Dusun Mertosanan Kulon, Desa Potorono, Kabupaten Bantul sebagai mitra kegiatan ini. LPPM UAD tidak terkait dalam penulisan artikel ini.

\section{Referensi}

Afiyatun. "Hubungan Peran Orang Tua Dengan Tingkat Pengetahuan Tentang Kesehatan Reproduksi Remaja Dalam Upaya Pencegahan Kehamilan Tidak Di Inginkan (Ktd) Di Sma N 2 Banguntapan Yogyakarta." Jurnal Keperawatan 2, no. 1 (2018).

Agus Miswanto, ANgga Prayuda, Aina Rufaida, Ulin Noor, Elok Nada Sofia, Alif Widi Sutani. "Pendampingan Remaja Untuk Mengatasi Problem Pernikahan Dini Dengan Penguatan Keterampilan Dan Wawasan Di Desa Rejosari, Wonoboyo Temanggung." Community Empowerment 6, no. 3 (2021): 352-359.

Arifah, Izzatul, Nugraheni Isna Muna, and Izdihar Azzah Paramastri. “Does Indonesian

${ }^{21}$ Aprilia Kartikasari and Nina Setiawati, "Bagaimana Komunikasi Orangtua Terkait Pendidikan Seks Pada Anak Remaja Mereka?,” Journal of Bionursing 2, no. 1 (2020): 21-27, http://bionursing.fikes.unsoed.ac.id/bion/index.php/bionursing/article/view/33/50.

22 Djama, "Kesehatan Reproduksi Remaja"; Kartikasari and Setiawati, "Bagaimana Komunikasi Orangtua Terkait Pendidikan Seks Pada Anak Remaja Mereka?"

23 Alif Widi Sutani Agus Miswanto, ANgga Prayuda, Aina Rufaida, Ulin Noor, Elok Nada Sofia, "Pendampingan Remaja Untuk Mengatasi Problem Pernikahan Dini Dengan Penguatan Keterampilan Dan Wawasan Di Desa Rejosari, Wonoboyo Temanggung," Community Empowerment 6, no. 3 (2021): 352-359. 
Adolescent Counseling and Information Center Affect Adolescent Reproductive Health Outcome?" EurAsian Journal of BioSciences 14, no. April (2020): 5347-5354.

Arum Dwi Anjani, Sisca Dwi Puspita. "Sapa Orang Tua Dengan Pengetahuan Remaja Tentang Kesehatan Reproduksi Remaja.” Jurnal Kebidanan 5, no. 4 (2019): 389-395.

BKKBN. "Survei Demografi Dan Kesehatan : Kesehatan Reproduksi Remaja 2017." Badan Kependudukan dan Keluarga Berencana Nasional (2017): 1-606. http://www.dhsprogram.com.

Denno, Donna M., Andrea J. Hoopes, and Venkatraman Chandra-Mouli. "Effective Strategies to Provide Adolescent Sexual and Reproductive Health Services and to Increase Demand and Community Support." Journal of Adolescent Health 56, no. 1 (2015): S22-S41.

Djama, Nuzliati Tahir. "Kesehatan Reproduksi Remaja." Jurnal Kesehatan Poltekkes Ternate 10, no. 1 (2017): 30.

Ernawati, Hery. "Pengetahuan Kesehatan Reproduksi Remaja Di Daerah Pedesaan." Indonesian Journal for Health Sciences 2, no. 1 (2018): 58.

Hidayat, Anas Rahmad, and Isnani Nurhayati. "Peran Orang Tua Dalam Pencegahan Perilaku Sex Pranikah Pada Remaja Di Bantul." Jurnal Formil (Forum Ilmiah) Kesmas Respati 5, no. 1 (2020): 71.

Indrijati, Herdina. "Penggunaan Internet Dan Perilaku Seksual Pranikah Remaja." Prosiding Temu Ilmiah Nasional X Ikatan Psikologi Perkembangan Indonesia 1, no. 17 (2017): 44-51. http://jurnal.unissula.ac.id/index.php/ippi/article/view/2178.

Isni, Khoiriyah, Fairuz Fatika, Novia Anggrahini Saputri, and Eva Lestari. "Upaya Penanggulangan Masalah Kesehatan Reproduksi Remaja Di Kecamatan Jetis, Yogyakarta." Jurnal Pemberdayaan: Publikasi Hasil Pengabdian Kepada Masyarakat 4, no. 1 (2020): 31-36.

Kartikasari, Aprilia, and Nina Setiawati. "Bagaimana Komunikasi Orangtua Terkait Pendidikan Seks Pada Anak Remaja Mereka?” Journal of Bionursing 2, no. 1 (2020): 21-27.

http://bionursing.fikes.unsoed.ac.id/bion/index.php/bionursing/article/view/33/ 50 .

Lestari, Widayati. "Model Komunikasi Pendidikan Seksualitas Orang Tua Pada Remaja Pendahuluan Maraknya Perilaku Seksual Remaja Saat Ini Sudah Semakin Memprihatinkan . Perkembangan Zaman Rangsangan Dari Lingkungan Seperti Film , TV , VCD Tentang Perilaku Seksual Serta Faktor." Indonesian Journal of Islamic Psychology 1, no. 1 (2019): 55-80.

Maulida, Desi, and Safrida Safrida. "Komunikasi Orang Tua Dan Anak Dalam Pencegahan Seks Pranikah.” Jurnal Komunikasi Global 9, no. 1 (2020): 97-114. 
Meilani, Niken, Zahroh Shaluhiyah, and Antono Suryoputro. "Perilaku Ibu Dalam Memberikan Pendidikan Seksualitas Pada Remaja Awal.” Kesmas: National Public Health Journal 8, no. 8 (2014): 411.

Moh.Ansori, Agus Afandi, Ries Dyah Fitriyah, Rizka Safriyani, Hernik Farisia. PendekatanPendekatan Dalam University Community Engagement. UIN Sunan Ampel Press, 2021.

Ramadhani, Livia Dwi, Tantut Susanto, and Latifa Aini Susumaningrum. "POLA KOMUNIKASI KELUARGA DENGAN PERILAKU SEKSUAL BERISIKO PADA REMAJA TUNARUNGU DI SEKOLAH LUAR BIASA KECAMATAN PATRANG KABUPATEN JEMBER." Jurnal Kesehatan Reproduksi 10, no. 1 (2019): 51-58.

Setiawati, Sari. Persepsi Remaja Terhadap Pernikahan Dini Di SMAN 1 Banguntapan Kabupaten Bantul, 2017.

Triani, Maria Margaretha Okky. "Isu Seksualitas Dalam Komunikasi Keluarga." Acta Diurna 16, no. 1 (2020): 70-91.

Utami, Fitriana Putri. "Praktik Orang Tua Dalam Pengawasan Pergaulan Remaja Guna Mencegah Kehamilan Tidak Diinginkan (KTD)." Care: Jurnal Ilmiah Ilmu Kesehatan 7, no. 2 (2019): 7-15.

Wibawa, Cahya. "Perbedaan Efektifitas Metode Demonstrasi Dengan Pemutaran Video Tentang Pemberantasan DBD Terhadap Peningkatan Pengetahuan Dan Sikap Anak SD Di Kecamatan Wedarijaksa Kabupaten Pati." The Indonesian Journal of Health Promotion 2, no. 2 (2007): 115-129. 